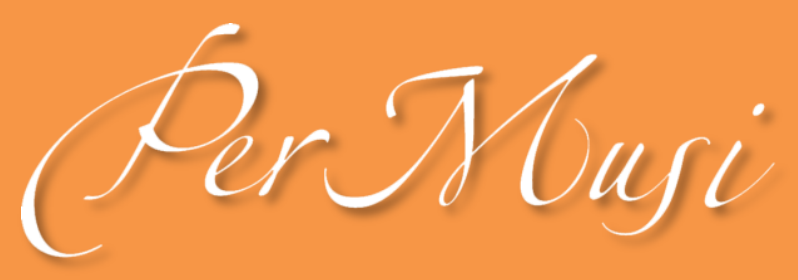

eISSN 2317-6377

\title{
Samba as Representation of Brazilianness in the Popular Songs Rhetoric
}

\author{
Claudia Helena Azevedo Alvarenga \\ https://orcid.org/0000-0002-6984-6069 \\ Universidade Federal do Rio de Janeiro, Colégio de Aplicação \\ alvarengacha@gmail.com
}

Tarso Bonilha Mazzotti

https://orcid.org/0000-0001-7461-9314

Universidade Federal do Rio de Janeiro, Faculdade de Educação; Universidade Estácio de Sá

tmazzotti@mac.com

SCIENTIFIC ARTICLE

Submitted date: 04 aug 2018

Final approval date: 13 mar 2019

\begin{abstract}
This article aims to examine the hegemonic representations of what is said "to be Brazilian". It proposes the rhetorical analysis of the lyrics of a couple of Brazilian popular songs in order to present the psychosocial aspects that bring to light the representations of social identity. The statement of identity and symbolic bonds through musicality exposes the desirable of the groups who share their value. The construct of social identity linked to nationality is a belief reinforced by social practices which relies on the metaphor that defines Music as the "people's soul".
\end{abstract}

Keywords: Social Identity; Rhetoric; Social Representations; Popular Music; Nationalism.

\section{SAMBA COMO REPRESENTAÇÃO DE BRASILIDADE NA RETÓRICA DO CANCIONEIRO POPULAR}

Resumo: Este artigo tem por objetivo examinar as representações hegemônicas do que se diz "ser brasileiro". Propõe-se a análise retórica de letras do cancioneiro popular brasileiro para apresentar os aspectos psicossociais que trazem à luz as representações de identidade social. A afirmação de vínculos identitários e simbólicos por meio das musicalidades expõe os desejáveis dos grupos que comungam acerca do seu valor. O constructo de identidade social vinculado à nacionalidade é uma crença reforçada pelas práticas sociais, que se sustenta na metáfora que define Música como a "alma do povo".

Palavras-chave: Identidade Social; Retórica; Representações Sociais; Música Popular; Nacionalismo.

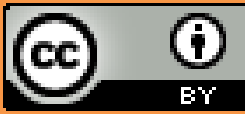




\section{Samba as Representation of Brazilianness in the Popular Songs Rhetoric}

Claudia Helena Azevedo Alvarenga, Universidade Federal do Rio de Janeiro, alvarengacha@gmail.com Tarso Bonilha Mazzotti, Universidade Federal do Rio de Janeiro e Universidade Estácio de Sá, tmazzotti@mac.com

\section{Musical issues and identity constitution}

What is your musical repertoire? This question is eventually posed by those who judge to be possible to trace someone's profile by one's set of favorite songs. Not coincidentally, on social networks, there is a demand to list them and to say which song is being played on the user's computer. Indeed the choice of music expresses and it is an expression of people's affective and cognitive experience as well as of shared values (Blacking 1973). In this perspective music is defined in the rhetorical or argumentative relation, in which this is the logos; that its producer (ethos, which expresses the pathos character) seeks to reach the listener (pathos, that suffers and evaluates what is given for appreciation). Regarding genre, musicality belongs to epideictic, whose purpose is to affirm and reaffirm social identity and group cohesion (Kennedy 1998; Perelman; Olbrechts-Tyteca 1971). Therefore, it is not feasible to analyze musical structures dissociated from their contexts and from social functions performed by them (Blacking 1973).

Musical repertoires are not merely personal. There are groups' repertoires which can be verified when conflicts arise about which soundtracks would be appropriate to ceremonies, celebrations and other situations of identity reaffirmation in face of threats. In such circumstances the symbolic and relatively stable cores of the group repertoire are resumed to express what is considered preferable to be, to have or to do.

This is a characteristic movement of social identity and representations formation processes. After all, the contents of everyday thinking are the ones to support the beliefs whose relations of coexistence between elements are established in social conversations, i.e., in rhetorical relations that trigger the reasoning that compares and categorizes objects and people, justifies actions and manifests values shared by groups, a cognitive operation that makes possible to systematize social environment (Moscovici 1988, 2012; Perelman and Olbrechts-Tyteca 1971).

For this article, we analyze popular songs whose narrative typifies Brazilian cultural ethos in three different psychosocial moments: (1) a romantic social identity representation of nostalgic character which exalt inner and unique Brazilian qualities linked to familiar language, blood and territory; (2) an attitude of facing the threats that an outgroup represent to Brazilian ethos; (3) the transformation of an unfamiliar genre into a recognizable one. 
This article places Samba on the proscenium of this debate since it is considered a symbolic core to define Brazilianness. Although this representation seems to be a simplification and has stereotyped characteristics, it is worth mentioning that Brazilian musicality, distinguished by Samba, is a long-standing representation that crosses the imaginary of Brazilian cultural identity, as we could recently observe in the Prize of Brazilian Popular Music that pays homage to a different leading composer or performer for each year. On the $25^{\text {th }}$ edition in 2014, the honored one was Samba, conceived as the matrix of Brazilian popular music. (Miguel 2014).

\section{Hegemonic Representations of Music}

The representation of music as a symbolic core of the group is sustained in the metaphor that defines music as "people's soul". This metaphor condenses and coordinates the meanings of music that became evident in the debate that has taken place in Brazil between 2005 and 2008, when the Ministry of Culture convened musicians and related professionals to prepare a proposal for a cultural policy for Brazilian music. One of the consequences was the approval of the Law which made music education a mandatory content in schools across the country (Alvarenga 2013).

A metaphor is an argumentative and rhetorical figure with an expressive and cognitive nature. The expressive quality is in established analog relationships which expose the preferable of the groups, besides guiding actions and performing the core function of social representations (Mazzotti 2003). Equally the metaphor has a cognitive quality because the similarities between approximated terms produce a condensed analogy whose familiar and well known meanings (phoros) are transferred to clarify or reframe what is the object of controversy (theme) (Perelman; Olbrechts-Tyteca 1971). Besides that, the use of metaphors is not restricted to the use of words and the use of language. It is the process of thought that is transferred to argumentation. "Most of our conceptual system is metaphorically structured; that is, most concepts are partially understood in terms of other concepts." (Lakoff; Johnson 1980, 56).

In regard to the process of identity constitution, the hegemonic aspect of social representations is revealed by the fact of not being forged in a particular group and still being shared by all its members, producing an effect of homogenization and stabilization of representations (Moscovici 1988). Still, it should be added that the conception of hegemonic representation is somehow intertwined with aspects of ideology, except for the meanings from which ideas are received, since social actors are not passive recipients. In this perspective, ideology is defined as a set of values and ideas shared by society which plays a relevant role not only in the identity constitution of social groups, but also in the organization for action (Xavier 2002). Moscovici $(1988,221)$ further states: "These hegemonic representations prevail implicitly in all symbolic or affective practices" and music is one of the social practices full of affective and symbolic links.

The affective and symbolic links are coordinated and condensed in the metaphor Music, the "people's soul" which is a result of analog comparison: music is for the people as the soul is to the body. Music (theme) is defined in relation with people for what is known (phoros) of the soul in relation to the body. The soul keeps the perennial core that confers the identity, the essence. The body is the visible manifestation of this essence which moves to signify the notion of people. Likewise music as an expression of the soul is a concept with roots on the common sense because musicality mobilizes affections. In this way, the metaphor links music to the idea of essence, to what is said to be the nature of things and beings, a core which establishes long-term predications, and that makes it possible to categorize the events that best embody an identity; that is the figurative model or the schema which provides meanings, i.e., the 
predicates of the sentence's subject - the people or the group - constituting a collection of categories that organizes the values and norms of the group (Moscovici 2012; Rateau et al. 2012).

Since musicality integrates the repertoire of elements that institute identities, it is necessary to recall them more frequently. The corpus of cultural traditions exists because it is systematically recalled. In the case of songs the repetition may occur in the re-recordings that contemporary musicians make of the songs composed by musicians of previous generations. Despite the arrangement variants, it is possible to recognize them although more daring arrangements may provoke controversy or even rejection. In addition, it is necessary to separate text (lyrics) and music that together produce the song. As a social practice, we share the meanings of experiences of interaction with music since musical experience do not communicate per se (Ferraz 2001).

In part this explains the fact that musicality schematizes the known contents (audio and discursive) and the ones naturalized in culture. In this perspective, the repertoire of songs is a musical channel of expression by combining sounds (rhythm, melody, timbre, harmony) and textual language; and by exposing beliefs, influences and conflicts around which the groups meet and mobilize. Musical productions concentrate group cultural expression in which artists synthesize the ethos of the group. Going even further, they act as mediators in the function of strengthening the communion when they bring together the links between symbols and what is symbolized, characteristics of the epideictic genre.

One conception of social identity is based on elements of culture and on the identification of the social actors with the cultures of their countries of origin which gives rise to the notion of national identity. Hall $(1995,612)$ states: "a nation is a symbolic community $[\ldots]$ ", that is, it is constituted by the representation of a national culture. In this sense, commemorative dates, rituals, arts - all these elements of the epideictic contribute to the idea of nation by producing the meanings that generate its representation and the feelings of communion and devotion.

Thus, in rhetorical perspective, the representations are fundamental in the formation processes of the identities. Values and behaviors produce the symbolic connections that the social groups understand as consistent with the interpretations and the acknowledgments of these manifestations in relation to something more comprehensive and stable, identified with the essence (identity) of the community. The reasoning based on relations of coexistence is relevant to understand the discursive mechanisms that reinforce the identifications shared by society since it links the manifestation to what is said to be an essence for constituting the social identities.

So, the arguments based on the structure of reality sustain the cultural identities inasmuch as they rely on beliefs and value judgements. The speaker generally establishes relations of coexistence between an act and the person who made it or between a manifestation and its essence, that is, the thought refers to reasoning that establishes symbolic connections and links certain phenomena as typical of a place, a time or a social group. The debate that establishes which manifestations best embody an essence points out the preferable defined by the groups.

Throughout the twentieth century, the Brazilian popular music repertoire problematizes the connection of musicality to what is typical of social identity through the approach of national. For this article, we chose to present three moments of Brazilian popular music with songs that allows us to examine the ethos of 
different phases and faces of Brazilian nationalism considering Samba, described as a musical genre that characterizes and distinguishes the Brazilian essence.

\section{Brazilian Popular Music}

After a season in the United States in the 1940s in which singer Carmen Miranda became somewhat rejected by the Brazilian audience, she records some Sambas which contents seek to affirm her Brazilian soul. Here we present excerpts from two Sambas by Vicente Paiva and Luiz Peixoto which convey this idea. The first one: I Returned to the Hill (Voltei pro Morro) ${ }^{1}$.

(...) Returning to the birthplace of Samba sung by me in other lands through the light that illuminates me I swear that without our melody and rhythm of tambourines many times I cried, I cried (...) (I Returned to the Hill, Vicente Paiva and Luiz Peixoto)

(...) Voltando ao berço do samba que em outras terras cantei pela luz que me alumia eu juro que sem a nossa melodia e a cadência dos pandeiros muitas vezes eu chorei, chorei (...) (Voltei pro Morro, Vicente Paiva e Luiz Peixoto)

The second Samba, They said that I returned Americanized, also reveals what is said to be typical of Brazilian musical identity.

They said I returned Americanized (...)

That I can not stand the brake of a tambourine

And I get goose bumps when listening to a cuíca (...)

That I no longer have mojo, rhythm or anything (...)

Over me, why so much poison?

I can stay there Americanized!

I who was born with Samba and live under the sky

Listening all night to the old batucada (...)

(They said that I returned Americanized, Vicente Paiva and Luiz Peixoto)

Disseram que eu voltei americanizada (...)

Que não suporto mais o breque do pandeiro

E fico arrepiada ouvindo uma cuíca (...)

Que já não tenho molho, ritmo, nem nada (...)

Mas pra cima de mim, pra que tanto veneno?

Eu posso lá ficar americanizada!

Eu que nasci com o samba e vivo no sereno

Topando a noite inteira a velha batucada

\footnotetext{
${ }^{1}$ We chose to present the original lyrics in Portuguese together with our translation.
} 
(Disseram que eu voltei americanizada, Vicente Paiva e Luiz Peixoto)

The songs are the singer's response to Brazilian nation (audience), stating that her essence was not corrupted by the charms of foreign lands (Albin 2001). "I who was born with Samba" announces the musicality that represents her because it runs in her veins. In "I returned to the Hill", the Samba essence is affirmed. It is marked by its origin linked to its homeland, the hill. ${ }^{2}$ Through the song's narrative you can map the shared manifestations that define Brazilian identity in opposition to the foreign one: (1) cadence and tambourine brake; (2) cuíca and tamborim (typical percussion instruments of the Samba school drumming section); (3) mojo and rhythm; (4) batucada (Samba style beat).

The arguments expose a national identity personification with a romantic nature, based on exaltation of people's qualities and on the feeling of complicity for inhabiting the same territory, speaking the same language and having a common history. In conjunction with the songs' narratives, it is essential to know the sounds of singing, of instrumental and rhythmic beats to apprehend how such a broad and diverse repertoire as the Samba can be registered and shared in this category by a whole nation. So, would Samba have remained the same over the decades? And would it be the same everywhere in Brazil? What does it mean to recognize it despite the diversity in which it is presented?

The narratives of the lyrics expose an implicit argument which is metaphorically structured: musicalities offer food for the soul just as the sap of the native land produces the food that nourishes the body. Therefore, the ethos of the nation is embodied by its music production. The contact with other cultures and the distance of the native land weaken the symbolic connections that are sustained on language, blood and a shared historical past. This situation is perceived as a threat to social identity so that the adaptation to the abroad is considered a negative value in this context.

According to Hobsbawm (1983), phenomena related to the concept of nation are invented traditions which rely on the establishment of formalized practices based on a real or an imagined past. For this author, the national identity is imagined and shaped in the search of a past that goes back to the origins and to the memories; on the feelings of communion and belonging; also on the spread of a legacy. The common symbolic vocabulary is based on a historical continuity from stratified and shared narratives, those that personify the nationalities among which the Brazilian. In the rhetorical conception, "whenever one wishes to make a group or an essence stable, concrete, and present, personification will be used. This argumentative figure makes it possible to stabilize the boundaries of the group and to give it coherence" (Perelman; Olbrechts-Tyteca 1971, 331).

At another moment, in 1959, Jackson do Pandeiro asserts the Brazilian identity by adopting a posture of confrontation with the Samba Chewing gum with Banana (Chiclete com Banana):

\author{
I will only put Bebop in my Samba \\ When Uncle Sam plays a tamborim \\ When he touches a tambourine and a zabumba (Brazilian bass drum). \\ When he learns that Samba is not rumba. \\ Then I'Il mix Miami with Copacabana.
}

\footnotetext{
${ }^{2} \mathrm{Hill}$ is the place where the previous free slaves lived, the favela. It refers to the slums at the urban areas where poor people live.
} 
I mix banana with chewing gum, and my Samba will look like this (...)

Look there, Samba-rock, my brother

Yes, but on the other hand,

I want to see a tambourine and a guitar Boogie-woogie.

I want to see Uncle Sam performing a Brazilian Samba beat with a skillet!

(Chewing gum with Banana, Jackson do Pandeiro)

Eu só boto bebop no meu samba

Quando Tio Sam tocar um tamborim

Quando ele pegar no pandeiro e no zabumba.

Quando ele aprender que o samba não é rumba.

Aí eu vou misturar Miami com Copacabana.

Chiclete eu misturo com banana, e o meu samba vai ficar assim (...)

Olha aí, o samba-rock, meu irmão

É, mas em compensação,

Eu quero ver um boogie-woogie de pandeiro e violão.

Eu quero ver o Tio Sam de frigideira numa batucada brasileira.

(Chiclete com Banana, Jackson do Pandeiro)

When the artist feels threatened by North-America's influence, he provokes Uncle Sam. He accepts contamination between cultures but without submission and, thereby, he exposes another side in which the Brazilian character recognizes and identifies itself: the ability to swallow and transform the culture through miscegenation in an attitude closer to anthropophagic movements.

The artist enumerates elements associated to feelings of "Brazilianness" (tambourine, tamborim, zabumba, banana, guitar and Copacabana) ${ }^{3}$ and those opposed to them (gum, bebop, rock, boogie-woogie and Miami). Chewing gum with Banana disqualifies the U.S. ability to mix Samba and Bebop without changing their inner characteristics. The implicit argument is: there is no better waddle than the Brazilian one ("I want to see a tambourine and a guitar boogie-woogie").

At various times Brazilian intellectuals attempted to describe the psychological characteristics of the Brazilian people. Leite (2007) locates four distinct positions: (1) the first occurs during the colonial period, still not nationalistic. It shows prevalence of admiration for nature's exuberance and appreciation of indigenous people; (2) the period after Brazil's independence seeks a positive image of the country by the great exaltation of nature and by romanticizing indigenous people who established the national ethos; (3) the pessimistic phase is inaugurated at the turn of the nineteenth to the twentieth century with basis on the evolutionary theories of Herbert Spencer in vogue in European thinking. The Brazilian people, a result of the miscegenation of three sad races (Portuguese, indigenous and black people), would have a degraded constitution; they would be an inferior race. This notion appears not only in music (e.g., lyrics by Vinicius

\footnotetext{
${ }^{3}$ Indeed banana has an Asian origin, in addition to the fact that it is grown in various regions of the planet. As for the neighborhood of Copacabana, it has been named by reference to the eponymous town on the shores of Lake Titicaca in Bolivia. See on Salazar, J. I. H. Copacabana, Ayurá y Cauca, tres topónimos indígenas en busca de explicación. Available at: http://www.redalyc.org/articulo.oa?id=255020409009. Accessed on: 09 feb. 2017.
} 
de Moraes) but also in literature (e.g., Olavo Bilac, Paulo Prado and Euclides da Cunha). Our comment intend to address the ideological origin of this representation of social identity that crosses Brazilian music and literature. The artistic creation that resumes the representation of identity by the bias of the three sad races, which occurred in several moments of Brazilian production, relies on Spencer's ideas that had great influence in European thinking from 1870 and spread throughout the American continent. Miscegenation becomes a theme and is transposed from body to soul by saying that the Brazilian person is mestizo (crossbreed) of blood and feelings as it appears in Carmen Miranda's songs presented above; (4) the reaction to such representation arises with the modernists who seek to accept Brazilian nature as it is, mocking those who despise the Brazilian mestizo nature, and celebrating the anthropophagic character of Brazilian culture which is clear from the analysis of Chewing gum with Banana song.

When comparing groups, it is common for members of a group to assign the best qualities to the group they belong to (ingroup) as well as the worst ones to opposition groups (outgroup). This is a psychosocial process of social categorization. The identity brings together a collection of characteristics believed to be possessed, mediated by representations that include, a priori and simultaneously, two meanings: (1) to make present the missing object, (2) to replace the missing object. To make it present and to replace it make it possible to realize many cognitive operations, including categorization (Deschamps; Moliner 2009; Moscovici 2012; Perelman; Olbrechts-Tyteca 1971).

The categorization processes, whether of objects or people, compare the elements to organize them and systematize the surroundings. Therefore, representations and beliefs formed with basis on these representations have influence on the chosen categories. In order to categorize it is necessary to reduce the amount of information about the object, a complex action when it comes to social categorization because the groups are in a web of categories woven by themselves. However, this cognitive work permits constituting a consensus about the object through simplification which leads to stereotyping. Besides cognitive function, the stereotype plays an evaluative role through the tendency to assert the superiority of the ingroup over the outgroup (Deschamps; Moliner 2009).

Since "national identities are not things we are born with, but are formed and transformed within and in relation to representation" (Hall 1995, 612), national cultures construct identities by producing meanings with which individuals can identify themselves. So a nation is a narration, a discourse on which narrative experiences shared by its members pass from the past to the future, from an idea of timelessness and immutability to compose the repertoire of traditions (Hall 1995; Hobsbawm 1983). The discursive strategies about the traditions, origins, histories, arts and symbols trigger the feelings of belonging of the individuals and their respective social identities.

In summary, these psychosocial processes explain Jackson do Pandeiro's discredit regarding Uncle Sam's abilities which is enough to challenge him musically when conferring the best attributes to Brazilian people. The adhesion of the Brazilian nation (audience) through the communion of beliefs on the superiority of Brazilian musicality over the others has strengthened the success of the song.

Over the same period, in the late 1950s, under the dominance of Jazz in Brazilian music, Carlos Lyra (Coisa mais linda 2005) composes Influence of Jazz (Influência do Jazz) as an act of protest.

My poor Samba,

It gradually got mixed and modernized 
and became lost

And the wiggle, where is it? There is no more.

Where is that waddle that stirs us up?

Pity, my Samba, that has suddenly changed,

It was influence of Jazz (...)

My poor Samba,

Go back to the Hill

and ask for help where you were born

So as not to be a Samba with too many notes

Not to be a lopsided Samba

swaying backwards and forwards,

It will have to do its best to get away from

the influence of Jazz

(Influence of Jazz, Carlos Lyra)

Pobre samba meu,

Foi se misturando se modernizando,

e se perdeu

E o rebolado, cadê? Não tem mais

Cadê o tal gingado que mexe com a gente?

Coitado do meu samba mudou de repente

Influência do jazz (...)

Pobre samba meu,

Volta lá pro morro

e pede socorro onde nasceu

Pra não ser um samba com notas demais

Não ser um samba torto

pra frente pra trás

Vai ter que se virar pra poder se livrar

da influência do jazz

(Influência do Jazz, Carlos Lyra)

The song structure relies on elements from Jazz, blending the sonorous vocabulary of this genre to Samba. The song sounds like an irony since it states that the Samba is no longer recognizable. Therefore, the Brazilian identity in trouble searches for its romanticized essence exposed in the song verses: (1) "go back to the Hill and ask for help where you were born": it is the rescue of authenticity whose strength is in the homeland; (2) in "where is that waddle that stirs us up?", Carlos Lyra evokes the collective memory anchored on an idiomatic waddle, the Samba waddle that Brazilians know and can acknowledge. However, this is the same identification that makes the new style or genre of music (Bossa Nova) in the early 1960s not yet categorized as truly Brazilian.

Influence of Jazz is initially seen as a modern way of playing Samba, therefore, it was not identified as a Brazilian product because it broke with the traditional Samba (Tinhorão 1986). In the early 1960s, it was an unfamiliar musicality. It caused reactions of curiosity and rejection, being understood by its hybrid quality. 
This ambiguous definition was not sufficient to establish the better defined outlines regarding the identity links that encompassed this musicality.

Like any social phenomenon that presents an unusual fact, as well as a threat to group identity, it is necessary to revise the agreement when the controversies are raised. The intragroup tension becomes transparent and to effect adjustments and negotiations, it is common for opinions to oscillate, causing reconstitution of the object or even rupture among group members. To make familiar the unfamiliar phenomena, allowing for revision of symbolic relations is one of the functions of social representations (Moscovici 2012). The phenomenon approach, which was unusual before, is touted by analogies, a cognitive operation that makes known what is strange, particular to the metaphorical process.

In this perspective, it is not possible to remain indifferent to the unknown, the Jazz, which makes the invention of Bossa Nova the expression of the desirable: the reaffirmed identity connections. What is relevant is the recognition of the Jazz influence on the Samba and its reorganization to reaffirm the national identity. Currently the Bossa Nova movement is recognized as a reference in Brazilian popular music, even as a national musicality brand for other countries.

\section{Final Remarks}

Besides describing the differences among social groups, great part of cultural experts sought to find the causes of diversity. According to the period, what prevailed were the trends that sometimes relied on agents of physical and physiological character (nature, race, psychology and culture relationship) and sometimes agents of social nature (e.g., history, education). These relationships, set forth as foundations for interpreting the descriptions of people, exposed the hegemonic or ideological representations. The attribution of causes and of specific origin to the phenomena that are forged out of the group and which constitute a network of stable schemes establish the hegemonic representations. In the case of cultural identities, these justifications "seem to reveal explicit or disguised forms of prejudice against foreigners and exaltation of their own culture" (Leite 2007, 173).

It is relevant to point out that the prevalence of one or other hegemonic representation does not imply a hierarchical succession since the ideological conceptions that support them are not surmountable. In fact, the representations are replaced or often they may coexist. Although nowadays the representation of social and economic development prevails in the discourse about Brazilianness, the national character stereotypes have not disappeared, as we may observe on jokes about the different nationalities.

In short, the exposure of speeches conveyed by the songs states the epideictic character of the music which supports the ethos of the group. The epideictic is the basis of social life because it brings to light the common values and the identification feelings among the members of a group. Music activities integrate this social landscape. Thus, it is coherent that certain popular repertoire turns into "classic", since it becomes part of a community's agreement, that which promote convergence and divergence among individuals and groups, typical of epideictic. In this way, Samba is expression of music diversity, identified as Brazilian, which display the relevance of music in delimiting identities.

Rhetorical analysis of lyrics in Brazilian popular songs exposes what Samba is said to be. As a result, it becomes feasible to expose the psychosocial processes of identity constitution that embody the Brazilian people, making it clear that musicality constitutes artifacts affirmation of social identity. Although our 
analysis encompasses only three specific situations of the broad Brazilian popular music scene, it is still possible to suggest that the reference for musicality and its identity bindings is constituted within the rhetoric relation which establishes its value to the social groups.

\section{References}

Alvarenga, Claudia Helena Azevedo. 2013. Música, a alma do povo. E-book. Poïesis Ed.. (Coleção Retórica e Argumentação na Pedagogia).

Blacking, John. 1973. How musical is man? Seattle and London: University of Washington Press.

Deschamps, Jean-Claude and Moliner, Pascal. 2009. A identidade em psicologia social: dos processos identitários às representações sociais. Tradução: Lúcia M. E. Orth. Petrópolis (RJ): Vozes.

Dicionário Cravo Albin da Música Popular Brasileira. 2001. Available at: <http://www.dicionariompb.com.br/>. Accessed on: Jan. 16, 2017.

Ferraz, Silvio. 2001. “Apontamentos sobre a escuta musical”. Música Hodie. Goiânia (1): 19-23.

Hall, Stuart. 1995. "The question of cultural identity". In: Modernity: an introduction to modern societies. Org. by S. Hall, D. Held. D. Hubert, K. Thompson. Open University/Blackwell: 596-632.

Hobsbawm, Eric. 1983. "Mass-Producing Traditions: Europe, 1870-1914". In: The Invention of Tradition. Org. by E. Hobsbawm; T. Ranger. 6. ed. Cambridge University Press: 263-307.

Kennedy, George A.. 1998. Comparative rhetoric: An Historical and Cross-Cultural Introduction. New York: Oxford University Press.

Lakoff, George and Johnson, Mark. (1980) 2003. Metaphors we live by. Chicago and London: The University of Chicago Press.

Leite, Dante Moreira. 2007. O caráter nacional brasileiro: história de uma ideologia. Org. by Rui Moreira Leite. 7 ed. rev. São Paulo: UNESP.

Mazzotti, Tarso Bonilha. 2003. "Metáfora: Figura Argumentativa Central na Coordenação Discursiva das Representações Sociais". In: Representações Sociais e Práticas Educativas. Org. by Pedro H. F. Campos; Marcos C. da S. Loureiro. Goiânia: Ed. da UCG: 89-102.

Miguel, Antonio Carlos. 2014. 25 anos - Prêmio da Música Brasileira. Org. by J. M. Machline. Rio de Janeiro: Edições de Janeiro.

Moscovici, Serge. 2012. A Psicanálise, sua imagem e seu público. Tradução: Sonia Fuhrmann. Petrópolis: Vozes.

Moscovici, Serge. 1988. "Notes toward a description of social representations". European Journal of Social Psychology 18: 211-250.

Perelman, Chaim and Olbrechts-Tyteca, Lucie. 1971. A New Rhetoric: a treatise on Argumentation. Translated by J. Wilkinson and P. Weaver. 2nd ed. Notre Dame/London, University of Dame Press.

Rateau, P., et al.. 2012. "Social Representation Theory". In: Handbook of theories of social psychology. Org. by P. A. M. Van Lange, A. W. Kroglanski and E. T. Higgins, (2). London: SAGE: 477-497.

Tinhorão, José Ramos. 1986. Pequena história da música popular: da modinha ao tropicalismo. 5a ed. rev. e aum. São Paulo: Art Editora. 
Xavier, Roseane. 2002. “Representação Social e Idelologia: Conceitos Intercambiáveis?". Psicologia \& Sociedade, Porto Alegre, 14 (2): 18-47.

\section{References of music videos}

Coisa mais linda: história e casos da bossa nova. 2005. Documentário. Direção: Paulo Thiago. Brasil: Sony Pictures. 1 DVD (120 $\mathrm{min})$. Available at: <http://www.youtube.com/watch?v=SjMSvuASw7E>. Accessed on: Jan. 14, 2017. 